|| ISSN(online): 2589-8698 || ISSN(print): 2589-868X || International Journal of Medical and Biomedical Studies

Available Online at www.ijmbs.info

PubMed (National Library of Medicine ID: 101738825)

Index Copernicus Value 2017: 40.03

Volume 3, Issue 3; March: 2019; Page No.209-220

\title{
A STUDY ON ASSESSMENT OF INJECTION PRACTICES IN VARIOUS HEALTH CARE SETTINGS OF KASHMIR VALLEY.
}

\author{
Uroosa Farooq Allaqband, Anjum B Fazili, Rohul Jabeen Shah and Walied K. Balwan* \\ Department of Community Medicine, Sher-i- Kashmir Institute of Medical Sciences, Soura, Srinagar.
}

Article Info: Received 03 March 2019; Accepted 30 March. 2019

Cite this article as: Allaqband, U. F., Fazili, A., Shah, R., \& Balwan, W. (2019). A STUDY ON ASSESSMENT OF INJECTION PRACTICES IN VARIOUS HEALTH CARE SETTINGS OF KASHMIR VALLEY. International Journal of Medical and Biomedical Studies, 3(3).

DOI: https://doi.org/10.32553/ijmbs.v3i3.165

Address for Correspondence: Dr. Walied K. Balwan, Department of Community Medicine, Sher-i- Kashmir Institute of Medical Sciences, Soura, Srinagar.

Conflict of interest: No conflict of interest.

\section{Abstract}

Background: Injection is an important drug delivery system especially for severely ill patients, acute emergency conditions and immunizations. But injections can spread disease to patients, healthcare workers, waste handlers and even in common healthy people if not used and disposed in proper way. Every year at least 16 billion injections are administered worldwide and at least half of them are unsafe. Breaks in safe injection practices coupled with overuse of injections may expose the recipients, healthcare workers or the community to several harms including life-threatening infections. Some factors that lead to unsafe injection practices include use of unsterile injection equipment, unsafe collection of sharps and management of injection related waste, reuse of contaminated needles and syringes and improper sterilization (especially of glass syringes).

Material and Methods: A cross sectional observational questionnaire based study was carried out in 40 healthcare facilities of two districts of Kashmir valley (one rural and one urban) selected purposively. The study was conducted amongst 152 injection providers in which 528 injections were observed. The study period was of 1 year from April 16-March 17. A prefabricated validity tested questionnaire was used to gather the requisite information. The questionnaire was divided into two parts. First part consists of questions on three types of observations and the second part consists of questions on four types of interviews.

Results: Out of total 528 injections observed $77.3 \%$ were curative (I/V, I/M) rest $22.7 \%$ were prophylactic (I/M, S/C, I/D). Majority of the providers resorted to practices which were unsafe and harmful to their being. These included practices like breaking glass ampoules without a protective barrier, nonuse of gloves in $97.3 \%$, re-capping of needles in $68.2 \%$, nonuse of needle destroyer in $85.8 \%$ and delay in disposal of used needle and syringes in a sharps container in $97.7 \%$ of health providers. Majority of the injection providers adopted practices which were unsafe for the patient/client. These included practices like preparation of injection on unclean surface, table or tray in 95.6\%, not washing hands before preparing injection 99.8\%, not cleaning hands with alcohol based hand rub in $98.5 \%$, not cleaning the rubber cap of multidose vial in $99.3 \%$ and palpating venipuncture site after skin preparation with antiseptic in $80.2 \%$.

Conclusion: As per the practice of providers, less than $1 \%$ of the providers washed their hands with soap and water before and $3.9 \%$ after the injection. In all the injections syringe and needle used were 
taken out from a sterile unopened packet. $95.6 \%$ of the injections were not prepared on a clean dedicated table or tray. None of the providers used a clean barrier to protect fingers when breaking the top of glass ampoules. Only $0.7 \%$ of providers cleaned the rubber cap of the multi-dose vial with antiseptic and $70.2 \%$ of providers removed the needle from rubber cap. In case of I/V injections, $90.1 \%$ of providers secured the patient and the intended puncture site before the procedure and none of them used a new pair of gloves before administering any type of injections.

Keywords: Injections, Health care settings, Healthcare workers.

\section{Introduction:}

Injection is an important drug delivery system especially for severely ill patients, acute emergency conditions and immunizations. But injections can spread disease to patients, healthcare workers, waste handlers and even in common healthy people if not used and disposed in proper way. Every year at least 16 billion injections are administered worldwide and at least half of them are unsafe. People residing in South-East Asian region receive 1.5 to 11.3 injections per person per year (1). The vast majority, around $90 \%$ of injections are given in curative care while immunization injections account for around $5 \%$. The remaining includes indications like transfusion of blood and blood products, intravenous administration of drugs and fluids and the administration of injectable contraceptives ${ }^{(2)}$.WHO defines a safe injection as 'one that does not harm the recipient, does not expose the healthcare worker to any avoidable risks and does not result in any waste that is dangerous to the community ${ }^{(3)}$. Unsafe injections can transmit bacterial, viral (HBV, HCV and HIV) and parasitic (malaria) infections ${ }^{(4)}$. Abscesses and septicemias may appear relatively quickly, while other infections may not be obvious for years or decades. In addition unsafe injections may also increase the risk of local trauma and nerve damage ${ }^{(5)}$. After an accidental needle-stick injury from a HBV infected source patient, the probability of infection for susceptible recipient averages $30 \%$. From HCV infected source, the probability of infection for susceptible recipient is 10 times smaller and averages 3\%. For HIV, the probability of infection for susceptible recipient after an accidental needle-stick is 100 times smaller than HBV and averages $0.3 \%$. Thus, while the transmission of HIV through unsafe injection is of particular concern because of severity, it is less common than HBV and HCV transmission. Hepatitis $B$ is the most likely pathogen transmitted through unsafe injections ${ }^{(6)}$. Breaks in safe injection practices coupled with overuse of injections may expose the recipients, healthcare workers or the community to several harms including life-threatening infections (4). Some factors that lead to unsafe injection practices include use of unsterile injection equipment, unsafe collection of sharps and management of injection related waste, reuse of contaminated needles and syringes and improper sterilisation (especially of glass syringes).

Estimates suggest that at least $50 \%$ of the world's injections administered each year are unsafe, particularly in developing countries. A majority of curative injections have been judged to be unnecessary, ineffective or inappropriate. Also in some countries of South-East Asia the proportion of unsafe injections is $75 \%{ }^{(1)}$. Global estimates arrived at by using mathematical models have suggested that unsafe injections account for $33 \%$ of new hepatitis B virus (HBV), $42 \%$ of new hepatitis C (HCV) and $2 \%$ of new HIV infections $^{(7)}$. This will pose a burden of 9.2 million disability adjusted life years (DALYs) between 2000 and $2030^{(8)}$. As per IPEN study group, three billion injections were estimated to be administered annually in India and out of those 1.89 billion were unsafe ${ }^{(1)}$.

\section{METHODS:}

A cross sectional observational questionnaire based study was carried out in 40 healthcare facilities of two districts of Kashmir valley (one rural and one urban) selected purposively. The study was conducted amongst 152 injection providers in which 528 injections were observed. 
The study period was of 1 year from April 16March 17. A prefabricated validity tested questionnaire was used to gather the requisite information. The questionnaire was divided into two parts. First part consists of questions on three types of observations and the second part consists of questions on four types of interviews as described below:

OBSERVATIONS: Healthcare facility, Injection practices, and Waste Handler.

INTERVIEWS: Prescriber, Provider, Waste Handler and Patient/Client (Exit interview).

Ethical clearance was obtained from the Institutional Ethics Committee. Besides this

Proper permission in writing was sought from the Director SKIMS/Director Health Services Kashmir/Principal GMC Srinagar (as applicable).Written informed consent was taken from the Head/In charge of each facility. Confidentiality was maintained at all times during the course of the study.

\section{STATISTICAL ANALYSIS:}

The standard statistical test like chi square $\left(x^{2}\right)$ was applied where ever required. All the results obtained have been discussed on $5 \%$ level of significance i.e. a $p$ value of $<0.05$ has been considered significant. The analysis of the data was done using SPSS version 20.00, Chicago, USA for windows.

\section{RESULTS:}

Table 1 depicts the distribution of facilities on the basis of type, level and location of health facility. A total of forty facilities were assessed out of which twenty were from urban and twenty from rural location. The facilities were again equally distributed among Govt. and Private sector with 20 facilities from each. However the ratio between primary and secondary/tertiary level facility was 3:2.

Fig. 1 shows the number and different type of observations and interviews by level of facility. A total of 40 facility observations were made in which 528 injections and 152 waste handlers were observed.152 interviews each of prescribers, injection providers, waste handlers and patients/clients were also conducted.

Fig. 2 shows that out of total 528 injections observed (77.3\%) were curative $(\mathrm{I} / \mathrm{V}, \mathrm{I} / \mathrm{M})$ rest (22.7\%) were prophylactic (I/M, S/C, I/D).

Table 2 depicts that majority of the providers resorted to practices which were unsafe and harmful to their being. These included practices like breaking glass ampoules without a protective barrier in all the providers, nonuse of gloves in $97.3 \%$, re-capping of needles in $68.2 \%$, nonuse of needle destroyer in $85.8 \%$ and delay in disposal of used needle and syringes in a sharps container in $97.7 \%$. The difference with regard to practice of using new gloves was statistically significant only by location of facility $(p=0.017)$. The difference in practice of re-capping the used needle and syringe was statistically significant as per the level, type and location of facility $(p=0.033,0.000 \& 0.040$ respectively). The difference in practice of nonuse of needle destroyer was statistically significant by type and location of facility $(p=0.000$ and 0.000 respectively). The difference in practice with regard to delay in disposing of used needle and syringe in sharps container was statistically significant only by type of facility $(p=0.023)$. However unsafe practices like bending or breaking of needle, manual removal of needle and manual transfer of needle from one container to another was seen only in $12.1 \%$, $1.1 \%$ and $0.2 \%$ of providers respectively. The difference in practice with regard to manual removal of needle from syringe was statistically significant as per level of facility $(p=0.014)$.

Table 3 reflects injection providers practice from patient safety perspective. Majority of the injection providers adopted practices which were unsafe for the patient/client. These included practices like preparation of injection on unclean surface, table or tray in $95.6 \%$, not washing hands before preparing injection $99.8 \%$, not cleaning hands with alcohol based hand rub in 98.5\%(the difference with regard to this practice was statistically significant only by location of 
facility $p=0.049$ ), not cleaning the rubber cap of multidose vial in $99.3 \%$ and palpating venipuncture site after skin preparation with antiseptic in $80.2 \%$ (the difference was statistically significant only by level of facility $p=0.000)$.

However some safe practices like use of needle and syringe from sterile unopened packet by all injection providers, removal of needle from the rubber cap of multidose vial after injection administration by $70.2 \%$ (the difference was statistically significant by level and type of facility $p=0.004 \& 0.001$ respectively), proper securing of patient and intended puncture site before I/V procedure by $90.1 \%$ ( the difference was statistically significant by level and location $p=0.001 \& 0.013$ respectively) and use of clean gauze pad to apply pressure to puncture site to stop bleeding in $88.1 \%$ were observed (the difference was statistically significant only by level of facility $p=0.000$ ).

Table 4 depicts the practice of injection providers as per patient/client safety perspective. Out of 528 injections observed 48 injections were observed in dental section. So there was no need of skin preparation before those injections. In $77.5 \%$ of prophylactic injections the skin was not cleaned as it was not visibly soiled and in $19.2 \%$ of injections the skin was not soiled and was cleaned with antiseptic swab/dry cotton. In $44.4 \%$ of I/M injections the skin was cleaned with antiseptic swab/dry cotton and in $100.0 \%$ of $\mathrm{I} / \mathrm{V}$ injections the skin was cleaned with antiseptic swab/dry cotton.

\begin{tabular}{|c|c|c|c|c|c|}
\hline \multirow{5}{*}{ Location } & \multirow{5}{*}{$\mathbf{N}$} & \multicolumn{4}{|c|}{ Type of facility } \\
\hline & & \multicolumn{2}{|l|}{ Govt. } & \multicolumn{2}{|l|}{ Private } \\
\hline & & \multicolumn{2}{|c|}{ Level of Facility } & \multicolumn{2}{|c|}{ Level of Facility } \\
\hline & & Primary & Secondary/Tertiary & Primary & Secondary/Tertiary \\
\hline & & $n$ & $n$ & $n$ & $\mathbf{N}$ \\
\hline Urban & 20 & 6 & 4 & 6 & 4 \\
\hline Rural & 20 & 6 & 4 & 6 & 4 \\
\hline Total & 40 & 12 & 8 & 12 & 8 \\
\hline
\end{tabular}

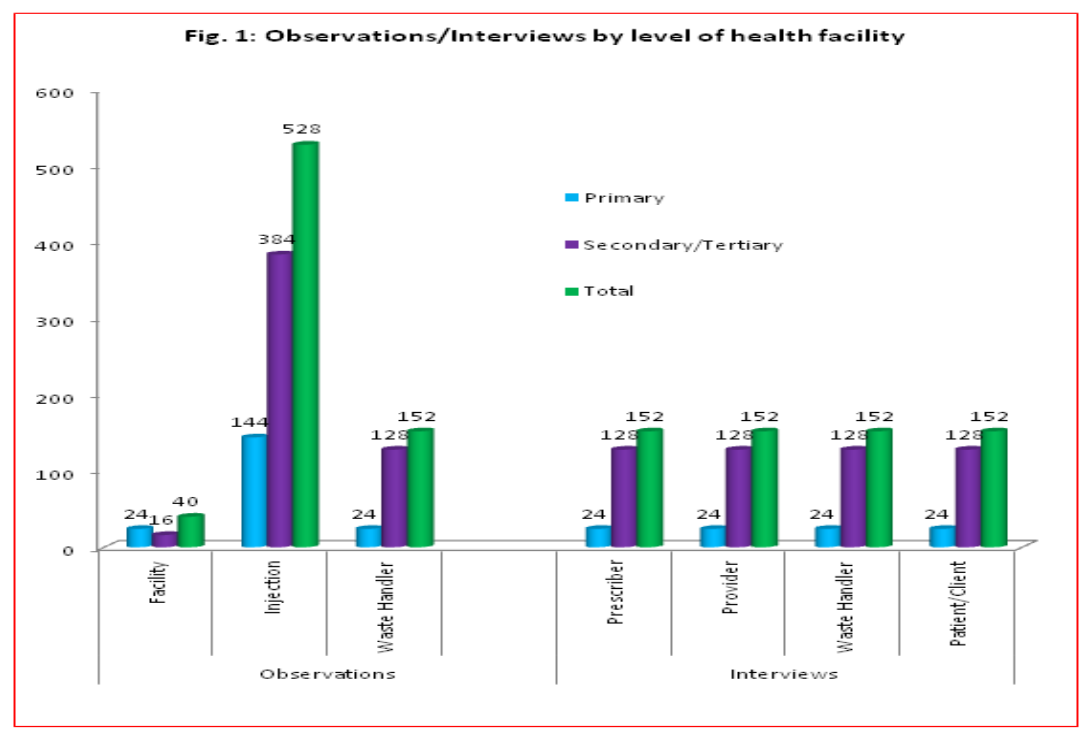




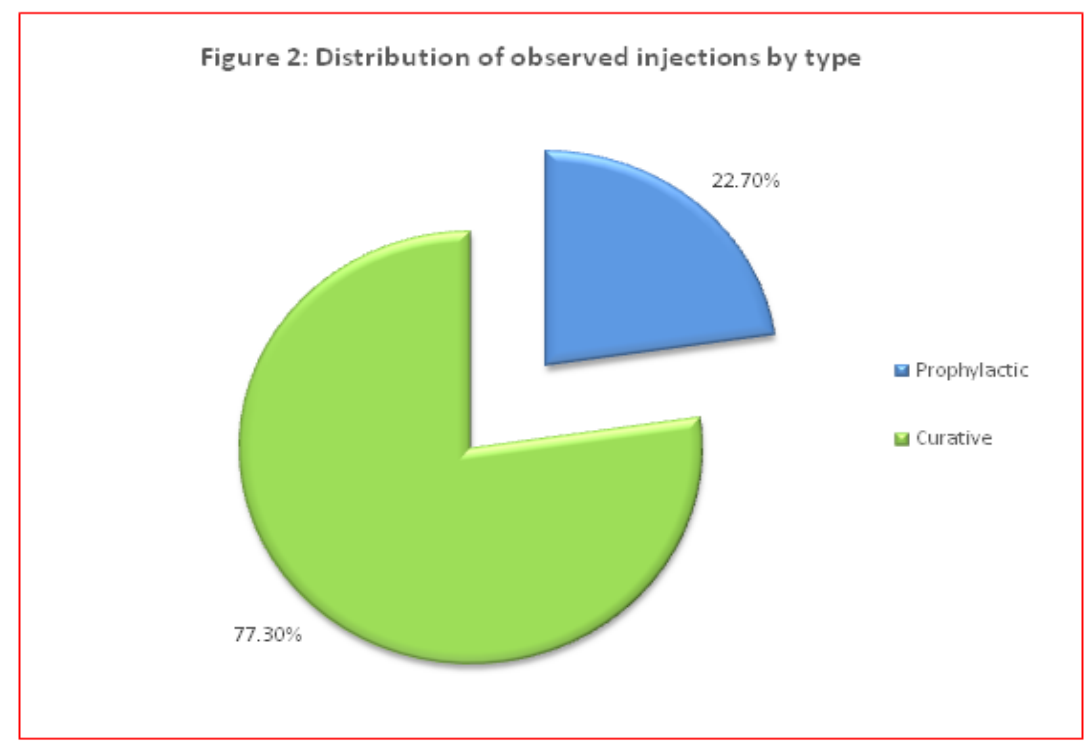

Table 2: Injection providers practice from provider safety perspective

\begin{tabular}{|c|c|c|c|c|c|c|c|}
\hline \multirow[t]{2}{*}{ Total } & \multicolumn{2}{|c|}{ Level of facility* } & \multicolumn{2}{|c|}{ Type of facility** } & \multicolumn{2}{|c|}{\begin{tabular}{|l|} 
Location \\
health \\
facility $* * *$
\end{tabular}} & \multirow{3}{*}{ P-value } \\
\hline & Primary & $\begin{array}{l}\text { Secondary/ } \\
\text { Tertiary }\end{array}$ & Govt. & Private & Rural & Urban & \\
\hline$N(\%)$ & n (\%) & n (\%) & n (\%) & n (\%) & n (\%) & n (\%) & \\
\hline
\end{tabular}

Was a clean barrier used to protect fingers when breaking the top from the glass ampoule(n=357)

\begin{tabular}{|c|c|c|c|c|c|c|c|c|}
\hline Yes & $\begin{array}{l}0 \\
(0.0)\end{array}$ & $\begin{array}{l}0 \\
(0.0)\end{array}$ & $\begin{array}{l}0 \\
(0.0)\end{array}$ & $\begin{array}{l}0 \\
(0.0)\end{array}$ & $\begin{array}{l}0 \\
(0.0)\end{array}$ & $\begin{array}{l}0 \\
(0.0)\end{array}$ & $\begin{array}{l}0 \\
(0.0)\end{array}$ & \multirow{2}{*}{$\begin{array}{l}* 0.633 \\
* * 0.904 \\
* * * 0.997\end{array}$} \\
\hline No & $\begin{array}{l}357 \\
(100.0)\end{array}$ & $\begin{array}{l}99 \\
(100.0)\end{array}$ & $\mid \begin{array}{l}258 \\
(100.0)\end{array}$ & $\begin{array}{l}157 \\
(43.9)\end{array}$ & $\begin{array}{l}200 \\
(56.0)\end{array}$ & $\mid \begin{array}{l}179 \\
(50.1)\end{array}$ & $\begin{array}{l}178 \\
(49.9)\end{array}$ & \\
\hline \multicolumn{9}{|c|}{ Did provider use a new pair of gloves $(n=528)$} \\
\hline \begin{tabular}{|ll} 
New gloves \\
used
\end{tabular} & $\begin{array}{l}14 \\
(2.7) \\
\end{array}$ & $\begin{array}{l}0 \\
(0.0) \\
\end{array}$ & \begin{tabular}{|l}
14 \\
$(3.6)$ \\
\end{tabular} & $\begin{array}{l}8 \\
(3.1) \\
\end{array}$ & $\begin{array}{l}6 \\
(2.3) \\
\end{array}$ & $\begin{array}{l}0 \\
(0.0) \\
\end{array}$ & $\begin{array}{l}14 \\
(5.3) \\
\end{array}$ & \multirow[b]{2}{*}{$\begin{array}{l}* 0.092 \\
* * 0.589 \\
* * * 0.017\end{array}$} \\
\hline $\begin{array}{ll}\text { No } & \text { gloves } \\
\text { used } & \end{array}$ & $\begin{array}{l}514 \\
(97.3)\end{array}$ & $\begin{array}{l}144 \\
(100.0)\end{array}$ & $\mid \begin{array}{l}370 \\
(96.4)\end{array}$ & $\begin{array}{l}256 \\
(96.9)\end{array}$ & $\begin{array}{l}258 \\
(97.7)\end{array}$ & $\begin{array}{l}264 \\
(100.0)\end{array}$ & $\begin{array}{l}250 \\
(94.7)\end{array}$ & \\
\hline \multicolumn{9}{|c|}{ Did the provider re-cap used needle and syringe $(n=528)$} \\
\hline Yes & $\begin{array}{l}360 \\
(68.2)\end{array}$ & $\begin{array}{l}88 \\
(61.1)\end{array}$ & $\begin{array}{l}272 \\
(70.8)\end{array}$ & $\begin{array}{l}159 \\
(60.2)\end{array}$ & $\begin{array}{l}201 \\
(76.1)\end{array}$ & $\begin{array}{l}191 \\
(72.3)\end{array}$ & $\begin{array}{l}169 \\
(76.1)\end{array}$ & $\begin{array}{l}* 0.033 \\
* * 0.000\end{array}$ \\
\hline
\end{tabular}




\begin{tabular}{|l|l|l|l|l|l|l|l|l|}
\hline No & $\begin{array}{l}168 \\
(31.8)\end{array}$ & $\begin{array}{l}56 \\
(38.9)\end{array}$ & $\begin{array}{l}112 \\
(29.2)\end{array}$ & $\begin{array}{l}105 \\
(39.8)\end{array}$ & $\begin{array}{l}63 \\
(23.9)\end{array}$ & $\begin{array}{l}73 \\
(27.7)\end{array}$ & $\begin{array}{l}95 \\
(23.9)\end{array}$ & $* * * 0.040$ \\
\hline \multicolumn{7}{|l|}{ Was needle remover } \\
\hline Yes & $\begin{array}{l}75 \\
(14.2)\end{array}$ & $\begin{array}{l}18 \\
(12.5)\end{array}$ & $\begin{array}{l}57 \\
(14.8)\end{array}$ & $\begin{array}{l}60 \\
(22.7)\end{array}$ & $\begin{array}{l}15 \\
(5.7)\end{array}$ & $\begin{array}{l}21 \\
(8.0)\end{array}$ & $\begin{array}{l}54 \\
(20.5)\end{array}$ & $\begin{array}{l}* 0.492 \\
* * 0.000\end{array}$ \\
\hline No & 453 & $\begin{array}{l}126 \\
(87.5)\end{array}$ & $\begin{array}{l}327 \\
(85.2)\end{array}$ & $\begin{array}{l}204 \\
(77.3)\end{array}$ & $\begin{array}{l}249 \\
(94.3)\end{array}$ & $\begin{array}{l}243 \\
(92.0)\end{array}$ & $\begin{array}{l}210 \\
(79.5)\end{array}$ & $* * 0.000$ \\
\hline
\end{tabular}

If disposable or safety syringe was used, did the provider immediately dispose off the needles and syringes in an appropriate sharps container after injection $(n=528)$

\begin{tabular}{|c|c|c|c|c|c|c|c|c|}
\hline Yes & $\begin{array}{l}12 \\
(2.3)\end{array}$ & $\begin{array}{l}0 \\
(0.0)\end{array}$ & \begin{tabular}{|l}
12 \\
$(3.1)$
\end{tabular} & $\begin{array}{l}12 \\
(4.5)\end{array}$ & $\begin{array}{l}0 \\
(0.0)\end{array}$ & $\begin{array}{l}3 \\
(1.1)\end{array}$ & $\begin{array}{l}9 \\
(3.4)\end{array}$ & 16 \\
\hline No & $\begin{array}{l}516 \\
(97.7)\end{array}$ & $\begin{array}{l}144 \\
(100.0)\end{array}$ & $\begin{array}{l}372 \\
(96.9)\end{array}$ & \begin{tabular}{|l|}
252 \\
$(95.5)$
\end{tabular} & $\begin{array}{l}264 \\
(100.0)\end{array}$ & $\begin{array}{l}261 \\
(98.9)\end{array}$ & $\begin{array}{l}255 \\
(96.6)\end{array}$ & $* * * 0.09$ \\
\hline
\end{tabular}

Did the provider bend or break the needle $(n=528)$

\begin{tabular}{|l|l|l|l|l|l|l|l|l|}
\cline { 1 - 5 } Yes & 64 & 16 & 48 & 25 & 39 & 37 & 27 & $* 0.663$ \\
& $(12.1)$ & $(11.1)$ & $(12.5)$ & $(9.5)$ & $(14.8)$ & $(14.0)$ & $(10.2)$ & $* 0.663$ \\
\cline { 1 - 3 } & 464 & 128 & 336 & 239 & 225 & 227 & 237 & $* 063$ \\
No & $(87.9)$ & $(88.9)$ & $(87.5)$ & $(90.5)$ & $(85.2)$ & $(86.0)$ & $(89.8)$ & $* * 0.184$ \\
\hline
\end{tabular}

Did the provider manually remove the needle from the syringe $(n=528)$

\begin{tabular}{|l|l|l|l|l|l|l|l|l|}
\hline Yes & 6 & 6 & 0 & 0 & 6 & 0 & 6 & $* 0.014$ \\
& $(1.1)$ & $(4.2)$ & $(0.0)$ & $(0.0)$ & $(2.3)$ & $(0.0)$ & $(2.3)$ & $* 0.0 .078$ \\
\hline \multirow{2}{*}{ No } & 522 & 138 & 384 & 264 & 258 & 264 & 258 & $* * * * 0.078$ \\
& $(98.9)$ & $(95.8)$ & $(100.0)$ & $(100.0)$ & $(97.7)$ & $(100.0)$ & $(97.7)$ & \\
\hline
\end{tabular}

Did the provider manually transfer the needles from one container to another $(n=528)$

\begin{tabular}{|l|l|l|l|l|l|l|l|l|}
\hline Yes & 1 & 0 & 1 & 1 & 0 & 0 & 1 & $*$ \\
& $(0.2)$ & $(0.0)$ & $(0.3)$ & $(0.4)$ & $(0.0)$ & $(0.0)$ & $(0.4)$ & $* .940$ \\
\hline \multirow{2}{*}{ No } & 527 & 144 & 383 & 263 & 264 & 264 & 263 & $* .500$ \\
& $(99.8)$ & $(100.0)$ & $(99.7)$ & $(99.6)$ & $(100.0)$ & $(100.0)$ & $(99.6)$ & \\
\hline
\end{tabular}

\begin{tabular}{|c|c|c|c|c|c|c|c|c|}
\hline & \multirow{2}{*}{ Total } & \multicolumn{2}{|c|}{ Level of facility* } & \multicolumn{2}{|c|}{ Type of facility** } & \multicolumn{2}{|c|}{$\begin{array}{l}\text { Location of health } \\
\text { facility*** }\end{array}$} & \multirow{3}{*}{ P-value } \\
\hline & & Primary & $\begin{array}{l}\text { Secondary } \\
\text { /Tertiary }\end{array}$ & Govt. & Private & Rural & Urban & \\
\hline & $N(\%)$ & n (\%) & n (\%) & $n(\%)$ & n (\%) & n (\%) & $\ln (\%)$ & \\
\hline \multicolumn{9}{|c|}{ Was injection prepared on visibly clean dedicated table or tray $(n=528)$} \\
\hline |Yes & $\begin{array}{l}23 \\
(4.4) \\
\end{array}$ & $\begin{array}{l}10 \\
(6.9) \\
\end{array}$ & $\begin{array}{l}13 \\
(3.4) \\
\end{array}$ & \begin{tabular}{|l}
14 \\
$(5.3)$ \\
\end{tabular} & $\begin{array}{l}9 \\
(3.4) \\
\end{array}$ & \begin{tabular}{|l}
10 \\
$(3.8)$ \\
\end{tabular} & \begin{tabular}{|l}
13 \\
$(4.9)$ \\
\end{tabular} & $\mid \begin{array}{l}* 0.080 \\
* * 0\end{array}$ \\
\hline No & $\begin{array}{l}505 \\
(95.6)\end{array}$ & $\begin{array}{l}134 \\
(93.1)\end{array}$ & $\begin{array}{l}371 \\
(96.6)\end{array}$ & $\begin{array}{l}250 \\
(94.7)\end{array}$ & $\begin{array}{l}255 \\
(96.6)\end{array}$ & $\begin{array}{l}254 \\
(96.2)\end{array}$ & $\begin{array}{l}251 \\
(95.1)\end{array}$ & $* * * 0.523$ \\
\hline
\end{tabular}




\begin{tabular}{|l|l|l|l|l|l|l|l|l|}
\hline \multicolumn{2}{|c|}{ Did the provider wash his/her hands with soap and water before preparing injection (n=528) } \\
\hline \multirow{2}{*}{ Yes } & 1 & 0 & 1 & 0 & 1 & 0 & 1 & $* 0.940$ \\
& $(0.2)$ & $(0.0)$ & $(0.3)$ & $(0.0)$ & $(0.4)$ & $(0.0)$ & $(0.4)$ & $* * 0.500$ \\
\hline \multirow{2}{*}{ No } & 527 & 144 & 383 & 264 & 263 & 264 & 263 & $* * * 0.500$ \\
& $(99.8)$ & $(100.0)$ & $(99.7)$ & $(100.0)$ & $(99.6)$ & $(100.0)$ & $(99.6)$ & \\
\hline
\end{tabular}

Did the provider cleanse her/his hands before preparing injection with alcohol based hand rub $(n=528)$

\begin{tabular}{|l|l|l|l|l|l|l|l|l|}
\hline Yes & 8 & 0 & 8 & 2 & 6 & 0 & 8 & $*$ \\
& $(1.5)$ & $(0.0)$ & $(2.1)$ & $(0.8)$ & $(2.3)$ & $(0.0)$ & $(3.0)$ & $* 0.198$ \\
\hline \multirow{2}{*}{ No } & 520 & 144 & 376 & 262 & 258 & 264 & 256 & $* 0.174$ \\
& $(98.5)$ & $(100.0)$ & $(97.9)$ & $(99.2)$ & $(97.7)$ & $(100.0)$ & $(97.0)$ & $* 0.049$ \\
\hline
\end{tabular}

Was syringe and needle taken from a sterile unopened packet or fitted with caps $(\mathbf{n}=528)$

\begin{tabular}{|l|l|l|l|l|l|l|l|l|}
\hline Yes & $\begin{array}{l}148 \\
(100.0)\end{array}$ & $\begin{array}{l}144 \\
(100.0)\end{array}$ & $\begin{array}{l}384 \\
(100.0)\end{array}$ & $\begin{array}{l}264 \\
(100.0)\end{array}$ & $\begin{array}{l}264 \\
(100.0)\end{array}$ & $\begin{array}{l}264 \\
(100.0)\end{array}$ & $\begin{array}{l}264 \\
(100.0)\end{array}$ & $* 0.625$ \\
$* * * 1.000$ \\
\hline No & 0 & 0 & 0 & 0 & 0 & 0 & 0 & $* * * 1.000$ \\
& $(0.0)$ & $(0.0)$ & $(0.0)$ & $(0.0)$ & $(0.0)$ & $(0.0)$ & $(0.0)$ & $* * 1.0)$ \\
\hline
\end{tabular}

If multidose vial was used did the provider clean rubber cap with antiseptic $(n=141)$

\begin{tabular}{|l|l|l|l|l|l|l|l|l|}
\hline Yes & 1 & 0 & 1 & 0 & 1 & 1 & 0 & $*$ \\
& $(0.7)$ & $(0.0)$ & $(1.00)$ & $(0.0)$ & $(1.9)$ & $(1.4)$ & $(0.0)$ & $* 0.875$ \\
\hline No & 140 & 42 & 98 & 87 & 53 & 72 & 68 & $* 0.332$ \\
& $(99.3)$ & $(100.0)$ & $(99.0)$ & $(100.0)$ & $(98.1)$ & $(98.6)$ & $(100.0)$ & $* * 0.525$ \\
\hline
\end{tabular}

If multidose vial was used was the needle removed from the rubber cap after withdrawing each dose for administration $(n=141)$

\begin{tabular}{|l|l|l|l|l|l|l|l|l|}
\hline Yes & 99 & 42 & 57 & 70 & 29 & 48 & 51 & $* 0.004$ \\
& $(70.2)$ & $(100.0)$ & $(57.6)$ & $(80.5)$ & $(53.7)$ & $(65.8)$ & $(75.0)$ & $* * 0.001$ \\
\hline No & 42 & 0 & 42 & 17 & 25 & 25 & 17 & $* * * 0.231$ \\
\hline
\end{tabular}

Did the provider appropriately secured the patient and intended puncture site so that patient could not move during procedure I/V $(n=101)$

\begin{tabular}{|c|c|c|c|c|c|c|c|c|}
\hline Yes & $\begin{array}{l}91 \\
(90.1) \\
\end{array}$ & $\begin{array}{l}12 \\
(66.7) \\
\end{array}$ & $\begin{array}{l}79 \\
(95.2) \\
\end{array}$ & $\begin{array}{l}43 \\
(89.6) \\
\end{array}$ & $\begin{array}{l}48 \\
(90.6)\end{array}$ & $\begin{array}{l}35 \\
(79.5) \\
\end{array}$ & \begin{tabular}{|l}
56 \\
$(98.2)$ \\
\end{tabular} & \multirow{2}{*}{$\begin{array}{l}* 0.001 \\
* * 0.868 \\
* * * 0.013\end{array}$} \\
\hline No & $\begin{array}{l}10 \\
(9.9)\end{array}$ & $\begin{array}{l}6 \\
(33.3)\end{array}$ & $\begin{array}{l}4 \\
(4.8)\end{array}$ & $\begin{array}{l}5 \\
(10.4)\end{array}$ & $\begin{array}{l}5 \\
(9.4)\end{array}$ & $\begin{array}{l}9 \\
(20.5)\end{array}$ & $\begin{array}{l}1 \\
(1.8)\end{array}$ & \\
\hline
\end{tabular}

Did the provider palpate venipuncture site after skin preparation with an antiseptic $(\mathrm{n}=101)$

\begin{tabular}{|l|l|l|l|l|l|l|l|l|}
\hline Yes & $\begin{array}{l}81 \\
(80.2)\end{array}$ & $(44.4)$ & $(83$ & 35 & 46 & 36 & 45 & $* 0.000$ \\
\hline No & 20 & 10 & 10 & $(72.9)$ & $(17.4)$ & $(81.8)$ & $(78.9)$ & $* * 0.086$ \\
& $(19.8)$ & $(55.6)$ & $(12.0)$ & 13 & 7 & 8 & 12 & $* * * 0.719$ \\
\hline
\end{tabular}

After procedure did provider used clean gauze pad and gently applied pressure to puncture site to stop bleeding I/V ( $\mathrm{n=101)}$

\begin{tabular}{|l|l|l|l|l|l|l|l|l|}
\hline Yes & 89 & 11 & 78 & 43 & 46 & 38 & 51 & $* 0.000$ \\
& $(88.1)$ & $(61.1)$ & $(94.0)$ & $(89.6)$ & $(86.8)$ & $(86.4)$ & $(89.5)$ & $* 0.0065$ \\
\hline No & 12 & 7 & 5 & 5 & 7 & 6 & 6 & $* * 0.665$ \\
& $(11.9)$ & $(38.9)$ & $(6.0)$ & $(10.4)$ & $(13.2)$ & $(13.6)$ & $(10.5)$ & $* * 0.632$ \\
\hline
\end{tabular}




\begin{tabular}{|c|c|c|c|c|c|c|c|c|}
\hline $\begin{array}{l}\mathrm{fte} \\
\text { ase }\end{array}$ & $\begin{array}{l}\text { roced } \\
\text { land }\end{array}$ & $\begin{array}{l}\text { id prc } \\
V(n=1\end{array}$ & ear & lan & hin & & & \\
\hline Yes & $\begin{array}{l}4 \\
(3.9)\end{array}$ & $\begin{array}{l}1 \\
(5.6)\end{array}$ & $\begin{array}{l}3 \\
(3.6)\end{array}$ & $\begin{array}{l}1 \\
(2.1)\end{array}$ & $\begin{array}{l}3 \\
(5.6)\end{array}$ & $\begin{array}{l}0 \\
(0.0)\end{array}$ & $\begin{array}{l}4 \\
(7.0)\end{array}$ & \\
\hline No & $\begin{array}{l}97 \\
(96.1)\end{array}$ & $\begin{array}{l}17 \\
(94.4)\end{array}$ & $\begin{array}{l}80 \\
(96.4)\end{array}$ & $\begin{array}{l}47 \\
(97.9)\end{array}$ & $\begin{array}{l}50 \\
(94.4)\end{array}$ & $\begin{array}{l}44 \\
(100.0)\end{array}$ & $\begin{array}{l}53 \\
(93.0)\end{array}$ & $\begin{array}{l}* * 0.376 \\
* * * 0.180\end{array}$ \\
\hline
\end{tabular}

\begin{tabular}{|l|l|l|l|l|l|l|}
\hline \multicolumn{6}{|c|}{ Table 4: Practice of skin preparation of patient/client by an injection provider before giving an } \\
injection
\end{tabular}

\section{DISCUSSION:}

Unsafe injection practices are increasingly recognized as a major source of infection with blood borne pathogens. While it is the responsibility of all health care workers, their employers, the public and national governments to ensure safe and appropriate use of injections, the prevention of blood borne pathogen transmission and other adverse events associated with injections will require improved collaboration between organizations and individuals sharing a common interest in attaining this goal. Unsafe injections can pose the infectious and non-infectious adverse effects in the form of HIV, HBV, HCV, abscesses and nerve injuries.

77.3\% injections were curative and $22.7 \%$ were prophylactic in our study. The commonest indications for curative injections were pain (29.9\%), infections (27.9\%), diarrhoea (13.48\%) followed by fever and road traffic accidents (10.0 $\%$ each). In a study from Bangladesh by Chowdhury AKA et al the commonest indications for injection use were acute diarrhoea (43.7 \%), skin infection/itching (23.5\%), fever (22.7\%) and traumatic injury/assault/road traffic accidents $(13.2 \%)^{\text {(9) }}$. A total of 528 injections were observed and the striking feature was that all the injections were unsafe with regard to any of the practices affecting either the safety of the patient/client, safety of the provider or safety of the community. IPEN study reports that at the country level nearly two thirds (62.9\%) of the injections administered were unsafe. The proportion of unsafe injections was higher in villages $(33.4 \%)$ as compared to those in urban areas $(26.6 \%)^{(1)}$.

\section{Practice from provider's safety perspective:}

Injection providers can be injured when breaking glass ampoules, which in turn can lead to contamination of the injectable medication or injection equipment. None of providers in our study used the clean barrier to protect their fingers while breaking glass ampoules. This was in accordance with the studies by Rehan HS et al from New Delhi and Bhargo L et al from Gwalior were none of the providers used protective barrier while breaking glass ampoules $(10,11)$. 
However Gyawali $S$ et al reported the use of such protective barrier in $41.9 \%{ }^{(12)}$. In USAID baseline report 2011, $9.3 \%$ of providers had observed this practice ${ }^{(13)}$. In our study only $2.7 \%$ of providers used new pair of gloves before administering injection which was in accordance with the study by Onyemocho $\mathbf{A}$ et al from Nigeria who reported use of gloves in $7.2 \%{ }^{(14)}$. Contrary to this a strikingly higher percentage of providers from studies by Enwere $\mathbf{O} \mathbf{O}$ et al from Nigeria and Koria B et al from Gujarat reported use of gloves in $92.2 \%$ and $86.7 \%$ providers respectively ${ }^{(15,16)}$. Recapping of needles after use is a wrong practice and has contributed significantly towards accidental needle stick injuries in health care providers during their practice. Our study revealed almost $70 \%$ of the providers resorted to the practice of recapping of needle after injection use. Enwere $\mathbf{0} \mathbf{0}$ et al reported recapping of needles in $44.8 \%$ and in $33.1 \%$ by Sahu D et al from Chhattisgarh $(15,17)$. Rehan HS et al have reported an encouragingly better figure (12.2\%) with regard to this practice (10). As per the BMW management rules use of needle destroyer after an injection event is considered as a safe practice. This practice was observed by only $14.2 \%$ of our injection providers. This is almost in accordance with a study from Andhra Pradesh by Garapati $\mathbf{S}$ et al who reported this practice in $21.7 \%{ }^{(18)}$. Further a dismally low percentage of 2.1 were reported by Gyawali $S$ et al ${ }^{(39)}$. However contradictory to the above Rehan HS et al reported use of needle destroyer by $79.2 \%{ }^{(10)}$. Sharps container was used for disposal of needles by $2.3 \%$ of providers in our study. Garapati $S$ et al reported safe disposal of used syringes in $21.3 \%$ (18). Contradictory to this a higher percentage of use of safety boxes for disposal of used needle and syringe was reported by Obi Al et al from Nigeria 95.9\% ${ }^{(19)}$ and Koria B et al from Gujarat (88.3\%) (16) $12.1 \%$ of our providers practiced bending or breaking of needles after use. Pathak R et al reported this practice in $19.6 \%$ and Kaphle HP et al in $48.6 \%^{(20,21)}$. The practice of manual removal of needles from used syringes can expose a provider to needle stick injury resulting in transmission of various blood borne infections. Encouragingly this unsafe practice was seen in only $1.1 \%$ of our providers which was in accordance with study by Sahu D et al who reported a percentage of $0.23^{(17)}$.

\section{Practice from patient /client safety perspective}

Injections were prepared on a visibly clean dedicated table or tray by mere $4.4 \%$ providers in our study. Contrarily in USAID baseline report 2011, 62.6\% and in a study by Chowdhury AKA et al from Bangladesh $35 \%$ providers had prepared injections on a clean surface ${ }^{(13,9)}$.

Hand washing with soap and water was observed by only $0.2 \%$ providers in our study which was contrary to the practices reported by Sahu D et al from Chhattisgarh and Kaphle HP et al from Nepal where $70.3 \%$ and $63.2 \%$ respectively washed their hands before preparing an injection $(17,21)$. However Garapati $S$ et al from Andhra Pradesh reported this practice as $18.2 \%$ (18) Cleansing of hands with alcohol based hand rub before preparation of injection by our providers was $1.5 \%$. Contrary to this a study by Ismail AA et al from Jazan reported use of alcohol hand rub by $85.5 \%$ providers ${ }^{(22)}$. A safe practice of using new unopened sterile syringe and needle was observed in all the injections in our study which is in accordance with the study from USAID baseline report 2011 and Chaudhuri SB et al from west Bengal ${ }^{(13,23)}$.

Swabbing of vial tops with an antiseptic or disinfectant is unnecessary. The septum of the vial must be pierced with a sterile needle and it should not be left in place in the septum. Cleaning of cap of multidose vail with antiseptic was practiced in $0.7 \%$ of our providers which is in accordance with study by Sahu D et al who reported non-existence of this practice in their study. In contrast, Gyawali $\mathbf{S}$ et al reported this practice in $52.2 \%\left(17,{ }^{12}\right)$. Needle was left in septum of multidose vial in $29.8 \%$ of injections in our study which is contrary to the study by Gyawali $S$ et al where it was observed in $4.4 \%$ (12). However Rehan HS et al from Delhi reported this practice by $44.6 \%$ of providers ${ }^{(10)}$. In our study, in $19.2 \%$ of prophylactic, $44.4 \%$ of $\mathrm{I} / \mathrm{M}$ and 
$100 \%$ of $\mathrm{I} / \mathrm{V}$ injection providers cleaned the injection site with antiseptic or dry cotton. Bhargo $\mathbf{L}$ et al from Gwalior reported that $100 \%$ providers cleaned the injection site before giving injection (11). In a study by Chowdhury AKA et al this practice was seen in $28.5 \%$, in Kaphle HP et al's study from Nepal it was $66.4 \%$ and Sahu D et al from Chhattisgarh reported it as $60.5 \%(9,21$, 17).

Patient movement during I/V injection administration could result in an accidental needle stick injury so securing the patient properly is important. This practice of securing the patient properly was observed in $90.1 \%$ of our observed injections which is in accordance with USAID baseline report 20011 where it was $89.6 \%^{(13)}$. Wrong practice of palpating the injection site after skin preparation with an antiseptic was observed in $80.2 \%$ of $\mathrm{I} / \mathrm{V}$ injections in our study. This is almost twice the figures reported from USAID baseline report 2011 where it was $40.5 \%{ }^{(13)}$. In $88.1 \%$ of I/V injections in our study clean gauze pad was used for application of pressure after the procedure. The corresponding figures reported from USAID baseline report 2011 was $69.3 \%{ }^{(13)}$.

\section{CONCLUSION:}

- As per the practice of providers, less than $1 \%$ of the providers washed their hands with soap and water before and $3.9 \%$ after the injection. $95.6 \%$ of the injections were not prepared on a clean dedicated table or tray. None of the providers used a clean barrier to protect fingers when breaking the top of glass ampoules. $70.2 \%$ of providers removed the needle from rubber cap.

- In case of I/V injections, $90.1 \%$ of providers secured the patient and the intended puncture site before the procedure and none of them used a new pair of gloves before administering injections. All of them cleaned the puncture site with antiseptic before the procedure but $80.2 \%$ of them touched the site with bare hands after cleaning and gentle pressure was applied on puncture site by a clean gauze pad in $88.1 \%$.
- Recapping was observed by $68.2 \%, 12.1 \%$ resorted to bending or breaking of needle, $1.1 \%$ manually removed the needle from syringe and $85.8 \%$ did not use a needle remover or destroyer.

\section{RECOMMENDATION:}

- There is a need for teaching and training at all levels of health care and across all cadres of health personnel. This should include all aspects of injection safety right from prescription of injections to disposal of injection related waste. More focus should be on hands on skill based training regarding various aspects like hygienic hand washing, safe handling of injection equipment, safe handling of patient while administering injections and safe segregation and final disposal of injection related waste.

- Health care personnel further need to be made aware on needle stick injury (NSI), its consequences and importance of timely reporting for early initiation of required PEP.

- $\quad$ There is a need to establish a proper system of reporting and documentation of NSI at the health facilities which should be the responsibility of the Infection Control Committee (ICC). The committee will ensure availability of adequate logistics for the provision of postexposure prophylaxis (PEP) as and when needed.

- Establish an infection prevention and control committee at facilities of the level of $\mathrm{CHC}$ and above which will ensure implementation of safe injection practices at their own facility and the facilities under their jurisdiction.

\section{REFERENCES:}

1. IPEN Study Group. Injection practices in India. WHO South-East Asia journal of public Health 2012; 1(2):189-200.

2. WHO. Guideline on the use of safetyengineered syringes for intramuscular, intra dermal and subcutaneous injections in health care settings. 2016. Available from http://apps.who.int/iris/bitstream/10665/25 0144/1/9789241549820-eng. Accessed on $20^{\text {th }}$ of March, 2016. 
3. WHO. Best practices for injection and related procedures tool kit .2010 March.

4. Kane A, Lloyd J, Zaffran M, Simonsen L, Kane M. Transmission of hepatitis $B$, hepatitis $C$ and human immunodeficiency viruses through unsafe injections in the developing world: model-based regional estimates. Bull World Health Organ 1999; 77: 801-7.

5. Simonsen L, Kane A, Lloyd J, Zaffran M, Kane $M$. Unsafe injections in the developing world and transmission of blood borne pathogens: A review. Bull World Health Organ 1999; 77:789-800.

6. Indian Academy of paediatrics. Guide Book on Safe Injection Practices. Available from http://www.iapindia.org/files/GUIDE_BOOK _ON_SAFE_INJECTION_PRACTICES. Accessed on $20^{\text {th }}$ November, 2016.

7. Safe Injection Global Network (SIGN). Advocacy booklet. Geneva. 2011; Available from http://www.who.int>injection_safety/ sign/advocacy_booklet/en/index.Accessed on 2 July 2015.

8. Hauri AM, Armstrong GL, Hutin YJF. The global burden of disease attributable to contaminated injections given in health care settings. Int J STD AIDS. 2004; 15(1):7-16.

9. Chowdhury $A K A$, Roy $T$, Faroque $A B M$, Bachar SC, Asaduzzaman M, Nasrin N et al. A comprehensive situation assessment of injection practices in primary health care hospitals in Bangladesh. BMC Public Health.2011; 11(779): 1-13.

10. Rehan HS, Chopra D, Sah RK, Chawla T, Agarwal A, Sharma GK. Injection practices of healthcare professionals in a Tertiary Care Hospital, New Delhi. Journal of Infection and Public Health. 2012; 5(2):177-181.

11. Bhargo $L$, Tiwari $R$, Jain $S$, Yuwane $P$, Rajpoot $M B$, Tiwari S. A study to assess injection practices at different levels of health care facilities in district Gwalior, M.P., India. Int J Res Med Sci. 2014; 2(3):1020-25.

12. Gyawali $S$, Rathore DS, Bhuvan KC, Shankar PR. Study of status of safe injection practice and knowledge regarding injection safety among primary health care workers in
Baglung district, western Nepal. BMC International Health and Human Rights 2013; 13(3):1-7.

13. U.S. Agency for International Development (USAID). Assessment of Injection Safety in Selected local government areas in five States in Nigeria. Baseline report 2011. https://aidsfree.usaid.gov/sites/default/files /assessment_of_injection_safety_nigeria_fol low-up. Accessed on 20 ${ }^{\text {th }}$ June 2015.

14. Onyemocho A, Anekoson JI, Pius EO. Knowledge and Practice of Injection Safety among Workers of Nigerian Prison Service Health Facilities in Kaduna State. American Journal of Public Health Research.2013; 1(7): 171-176.

15. Enwere OO, Diwe KC. Knowledge, perception and practice of injection safety and healthcare waste management among teaching hospital staff in south east Nigeria: an intervention study. Pan African Medical Journal.2014; 17: 218.

16. Koria B, Lala MK. A study of knowledge, attitude and practice of hepatitis-B infection among the laboratory technicians in the civil hospital, Ahmedabad, Gujrat. Health line. 2012; 3(1); 63-65.

17. Sahu D, Gandhi N. Assessment of Safe Injection Practices in a Tertiary Care Hospital: A cross-sectional study from Chhittisgarh. National Journal of Community Medicine. 2015; 6(4):500-503.

18. Garapati S, Peethala S. Assessment of knowledge and practices on injection safety among service providers in east Godavari district of Andhra Pradesh. Indian Journal of Community Health 2014; 26(3): 259-263.

19. Obi Al, Ofili AN. Injection Safety Practices among Medical Doctors in a Tertiary Health Institution in South Southern Nigeria. Journal of Dental and Medical Sciences.2013; 8(1):42-49.

20. Pathak R, Kahlon AS, Ahluwalia SK, Sharma $S$, Bhardwaj R. Needle Stick Injury and Inadequate Post Exposure Practices among Health Care Workers of a Tertiary Care Centre in Rural India. International Journal of 
Dr. Walied K. Balwan et al, International Journal of Medical and Biomedical Studies (IJMBS)

Collaborative Research on Internal Medicine \& Public Health.2012; 4(5): 638-648.

21. Kaphle HP, Poudel S, Subedi S, Gupta N, Jain $V$, Paudel P. Awareness and Practices on Injection Safety among Nurses Working in Hospitals of Pokhara, Nepal. Int J Med Health Sci. 2014; 3(4): 301-307.

22. Ismail AA, Mahfouz MS and Makeen A. Injection safety among primary health care workers in Jazan Region, Saudi Arabia. The International Journal of Occupational and Environmental Medicine. 2014; 5(3).

23. Chaudhuri SB, Ray K. Safe Injection Practices in Primary Health Care Settings of Naxalbari Block, Darjeeling District, West Bengal. Journal of Clinical and Diagnostic Research. 2016; 10(1):1-7. 